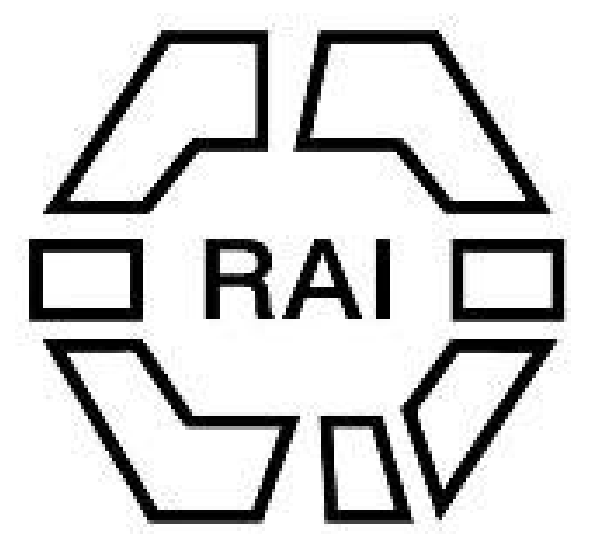

\title{
WILEY
}

78. Egyptian Palaeoliths.

Author(s): W. M. Flinders Petrie

Source: Man, Vol. 21 (Sep., 1921), pp. 129-130

Published by: Royal Anthropological Institute of Great Britain and Ireland

Stable URL: http://www.jstor.org/stable/2840761

Accessed: 27-06-2016 09:03 UTC

Your use of the JSTOR archive indicates your acceptance of the Terms \& Conditions of Use, available at

http://about.jstor.org/terms

JSTOR is a not-for-profit service that helps scholars, researchers, and students discover, use, and build upon a wide range of content in a trusted digital archive. We use information technology and tools to increase productivity and facilitate new forms of scholarship. For more information about JSTOR, please contact support@jstor.org.

Royal Anthropological Institute of Great Britain and Ireland, Wiley are collaborating with JSTOR to digitize, preserve and extend access to Man 


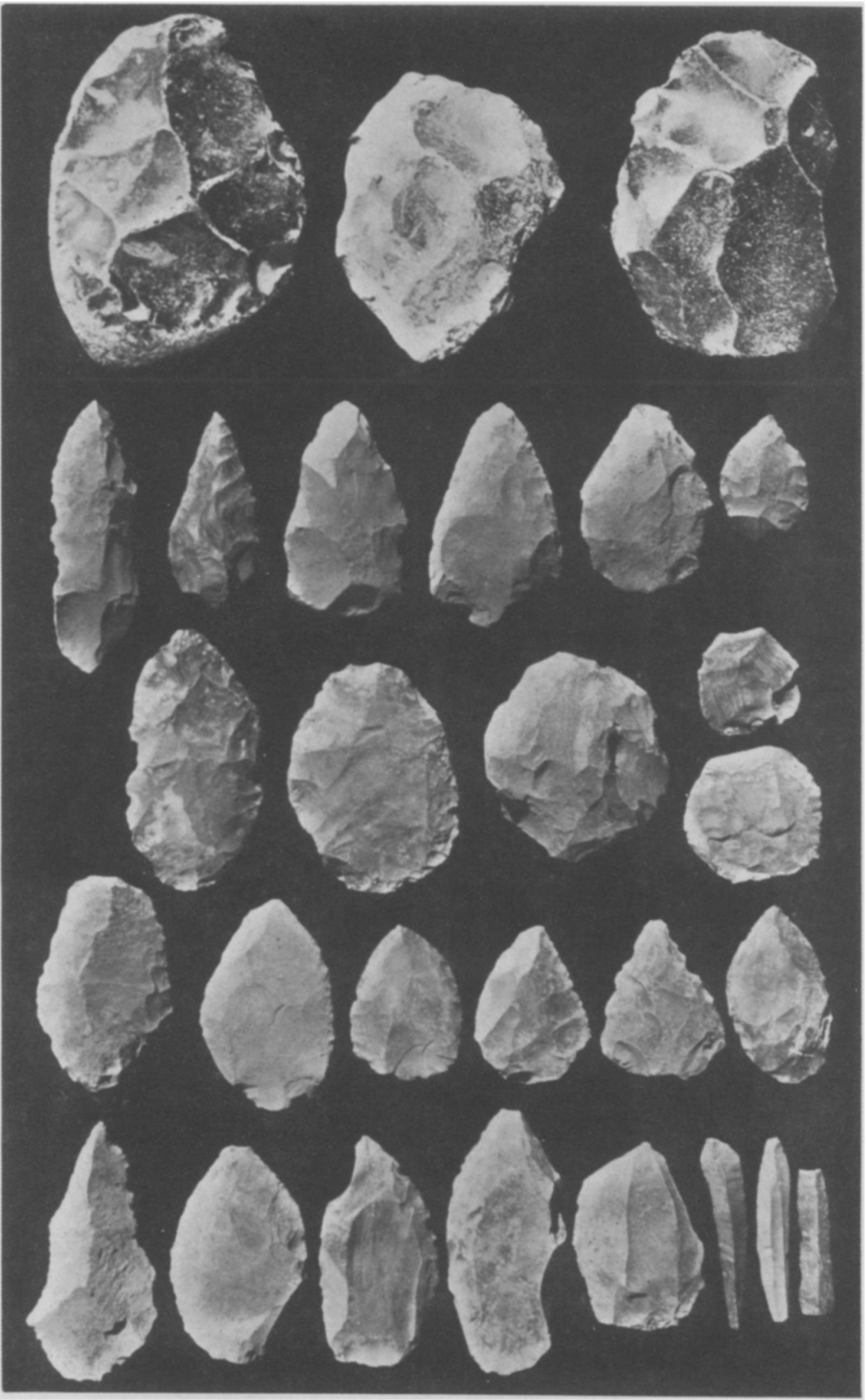

EGYPTIAN PALAELITHS,

Scale $2 / 5$

This content downloaded from 137.99.31.134 on Mon, 27 Jun 2016 09:03:42 UTC All use subject to http://about.jstor.org/terms 


\section{Egypt: Archæology.}

Egyptian Palæoliths. By Professor W. M. Flinders Petrie, F.R.S.
Recent work of the British School in Egypt has added to the material for anthropology in several ways. The flint work-or rather chert-found in the Nile valley is almost all of isolated surface specimens, and any more definite connections are much needed.

On the outskirts of Cairo the road to Gebel Ahmar on the north-east passes a great gravel pit whence road and building material is taken. The mass of sand, flints and blocks of fossil wood has evidently been rolled down by torrential rains from the petrified forest six miles back on the high desert. It belongs, therefore, to a pluvial period which is older than the Chellean and later ages, the remains of which lie undisturbed on the surfaces where made or dropped. In this gravel were the three flints at the top of the plate; they are highly polished by sand wear in running water, as well as abraded on the edges. The early age of these agrees with the resemblance they bear to the subecrag flint work of East Anglia.

In the neighbourhood of the pyramid of Lahun, at the mouth of the Fayum, there is a high bed of old Nile mud, rising twenty feet above the present high Nile, and therefore still more above the Nile of any age since the last great submersion. Upon a weathered plain of this mud, at the present high Nile level, was a settlement which left worked flints thickly strewn over an area two or three hundred feet across. No others of the same type are found in the neighbourhood, and from the small and definite area it seems that they are all contemporary, and equivalent to a definite horizon in deposits. Examples of the various types are in the lower part of the plate. Most are bi-convex forms, some finely worked over the whole faces. Others are plano-convex and the working approaches long flaking, while a few long flakes occur. The general type is Mousterian, the skew points with flat backs being distinctive; others border on Solutrean forms, though none of the characteristic Solutrean types of the Fayum desert are found. The conclusion of good authorities is that we may best term these late Mousterian. We already know the Magdalenian types in the prehistoric civilisation of Egypt, the Solutrean on the desert of the Fayum, the Aurignacian types from a settlement with ashes at Naqadah, and now we find the Mousterian in this settlement showing that the Nile has not been as high since that time. The British Museum will receive the three earliest flints and a selection of the Mousterian.

Excavations have produced material of various ages. From the late prehistoric is a dried body of a girl of about 18, who was buried in the natural attitude of sleep with a hand bent over beneath the face. The skin remains on much of the body and head. A cemetery of the first dynasty contained all the types of tomb from open graves to deep chambers with portcullis slabs, in use at the same time, suggesting a variety of tribes. The open graves had bodies much taller than those in the chambered tombs, agreeing with the prehistoric people at Tarkhan, being four inches taller than the dynastic invaders. The second dynasty people were measured in a cemetery at Sedment, which provided a large quantity of alabaster and some copper vases. The ninth and tenth dynasties, of which nothing was yet known, were largely buried at Sedment, which was the cemetery of their capital, later known as Herakleopolis. Dozens of skulls were obtained and measured. All of the skulls that could safely be moved have been placed with Professor Karl Pearson at University College.

Many fine artistic works, of various ages before 1200 B.c., were also found this year, and are being distributed to museums. Unfortunately the bad support of collections in this kingdom obliges the School to depend mostly on foreign museums 
for maintaining the training of British students in return for the objects discovered. The expenditure of money on profitless amusements instead of permanent results is a deplorable blot on the present age.

W. M. FLINDERS PETRIE.

Malta: Technology.

Buxton : Hort. The Modern Pottery Industry in Malta. By L. H. Dudley Buxton, 79
M.A. and A. V. D. Hort.

The following notes were collected by Mr. A. V. D. Hort during the visit of the Oxford Anthropological Expedition to Malta, and form a part of the report of the Expedition which it has been found more convenient to publish separately. As the Expedition was compelled, owing to shortness of time in the island, to concentrate on certain aspects of Maltese life, it was not found possible to do more than visit the potteries in one part of the island.

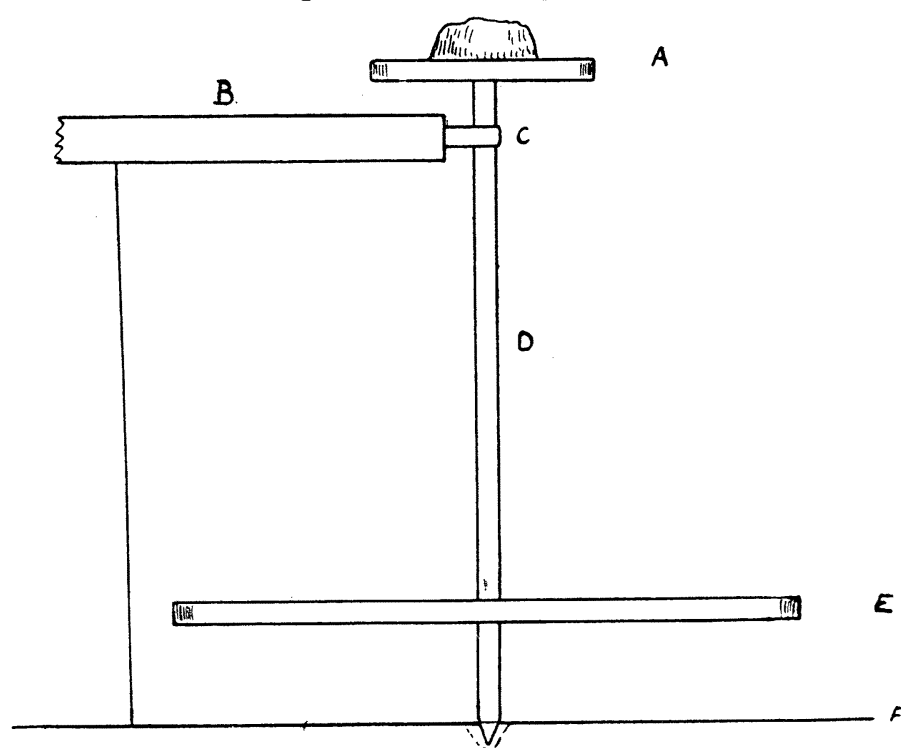

Pottery is made at Zeitun and Birchircara. At the latter place two methods are in use, an older and a new. In the old method (Fig. II.) a baked clay support (B) in the form of a truncated cone with a maximum diameter of about 10 centimetres, narrowing to four or five on the top, and about three centimetres high, is used. On this

E support a wooden disc (A) is set and sprinkled with sand to prevent the clay from sticking

Fig. I.-NEW TYPE.

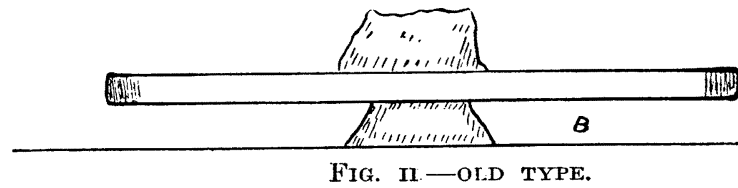

to the disc. The clay itself is also rolled in sand, and then a flat piece is laid on the disc, which is set spin$c$ ning by the hand in a clockwise direction,

and a broad strip of clay is laid round the piece already on the turntable to form the walls of the pot. If necessary a second piece is worked on top of this. The hand is wetted and the pot shaped. As soon as it is finished it is lifted off and put aside to dry. The inside and out are smoothed with a small piece of wcod. When the pot is nearly dry it is polished with a pebble, but the potters say that it is impossible to get a high polish on the clay they use. This type of wheel is still used for making some vessels, e.g., the olla, a large water-pot about two feet high, with a narrow neck and a handle on either side, but the younger generation for the most part do not know how to use the old method.

The more modern wheel (Fig. I.) consists of an iron spindle with a pointed lower end (D). The spindle is set upright with the point in the native rock floor (F). It is sufficiently tall to clear the top of a wooden bench (B) to the edge of which it is attached by a bearing $(\mathrm{C})$ which allows it to rotate freely. A wooden turntable (A) is placed on top of the spindle which passes through the centre of a wooden disc (E)

$$
\text { [ } 130 \text { ] }
$$

